\title{
New Employment Experiences and Trajectories between Salary-earning and Entrepreneurs
}

\author{
Isabela Paes ${ }^{1, *}$, Geraldine Guerillot ${ }^{2}$, Jean-Luc Moriceau ${ }^{1}$, Julien Billion ${ }^{2}$ \\ ${ }^{1}$ Institut Mines Telecom/Telecom Business School, France \\ ${ }^{2}$ Umalis Lab, Umalis Group, France
}

Copyright $(\subset 2015$ by authors, all rights reserved. Authors agree that this article remains permanently open access under the terms of the Creative Commons Attribution License 4.0 International License

\begin{abstract}
Traditionally, as well as in pop culture, entrepreneurship is conceived of as opposed to salary-earning, and decision from being a salaried employee to entrepreneur as a great leap. However, entrepreneurship studies and new employment forms blur this border between two worlds and the plunging from one world to the other. A study is conducted on employees working at this frontier: French umbrella professionals (salariés portés), inquiring qualitatively about their conception of entrepreneurship, their experience of crossing and of their new condition, as well as their aspirations, fears and values. No leap in activity was found, but there was the feeling of having shifted to another mental universe. The respondents had all the feeling of being entrepreneurs without creating new products, markets or business ventures. They enjoy their full engagement in their work and experience a different relation to time. Considering themselves as entrepreneurs grants them with a desirable social status, but underscores their risky position and an increased portion of their life to be devoted to work. This study aims at providing guidance for public policies fostering employment through entrepreneurship and for workers considering such a working hybrid status. It also puts into perspective the classical contours of entrepreneurship and salaried positions and call for closer examination of the new forms of employment.
\end{abstract}

Keywords Independent Workers, Umbrella Company, Work Experience, Career Trajectory, Entrepreneurship

\section{Introduction}

Traditionally, as well as in pop culture, entrepreneurship is conceived of as opposed to salary-earning, and decision from being a salaried employee to entrepreneur as a great leap, a "plunge decision". However, entrepreneurship studies and new employment forms blur this border between two worlds and the plunging from one world to the other. However, entrepreneurship studies [1-2] and the development of new forms of employment [3-5] blur this border between two worlds and the plunging from one world to the other. The distinction between employee and entrepreneur, previously clear and sharply cut, becomes blurred with the emergence of new practices on the frontier of these two statuses. The border separating two worlds, as well as the leap from one to the other, are open to discussion.

Thus, employments in such a hybrid situation are growing, populating the frontier between salary-earning and entrepreneurship with a range of different possible statuses. This is particularly the case among professionals who are experts in their field. Nevertheless, are such hybrid situations transition steps in the direction of entrepreneurship? To start to answer to this more general question, we will focus on this narrower interrogation: what kind of motivation, desire, fear and value drive professionals who opt for such a status?

To learn more about these new forms of employment and breed of workers is notably valuable today in a Europe confronted with unemployment and public deficits. Policies are many attempting to return to growth through the development of entrepreneurship and flexibility measures while they are trying to maintain, as much as possible, social protection. Innovation in hybrid and novel work statuses could help solve these potentially contradicting objectives. This study aims at providing guidance for such policies and for workers considering a hybrid working status. It also hopes to contribute providing a better insight into new aspects of entrepreneurship today.

An in-depth study was conducted on the trajectories of 10 consultants in a rapidly growing new hybrid form of employment in France: the "portage salarial". This study highlights that rather than a plunge from one status to the other, there are bridges, possibly transient, linking them. However, every status corresponds to very different psychological universes, in which relationships with activity and with time are clearly different to the other universes. The "portage salarial" corresponds to a seemingly paradoxical situation, in which the professional has a status of employee but without subordination and in which he/she has the 
feeling of being an entrepreneur without creating business or new products/markets. Considering him/herself as entrepreneur grants her with a desirable social status, but underscores her risky position and an increased portion of her life to be devoted to work.

After a literature review emphasizing some major evolutions in the concept of entrepreneurship and analyzing the rise of new forms of employment, we present our two-step qualitative method conducted with 10 professionals in positions of portage salarial inside the data processing and telecommunication sectors. Findings and analysis are then presented about trajectories to and from the portage salarial, and about how this status is experienced. We conclude on the need to reconsider the border between entrepreneurship and salary-earning positions and on the possibilities and dangers of these new employment forms.

\section{Literature Review}

Looking at the evolution of the very concept of entrepreneurship in entrepreneurship studies make us see how it has evolved from the image of the entrepreneur portrayed as an exceptional character to a creative and design activity. Until the beginning of this century, researches mainly focused on entrepreneurs' distinctive skills and attitudes or on the relative performance of entrepreneurial ventures compared to in-company developments. Shane and Venkataraman [1] proposed a reconceptualization of the field of study replacing the perspective on who is the entrepreneur and what he or she does by a definition of the field "as the scholarly examination of how, by whom, and with what effects opportunities to create future goods and services are discovered, evaluated, and exploited" (Venkataraman quoted by [1, p.218]). Entrepreneurial opportunities that remain to be discovered, evaluated and exploited are thus introduced, and it is this encountering of opportunities that triggers the decision of becoming an entrepreneur. Becoming entrepreneur is no longer a great leap, it is the outcome of a process. This approach is extended ten years afterward by Sarasvathy and Venkataraman [2] for which entrepreneurship becomes a "method of human action" (p. 130). A method likely to be learned by anyone, as is the scientific method. A method is not merely consisting in discovering and exploiting opportunities but also in creating them. The great leap becomes a learning trajectory.

Research focus then moves to the actions, strategies, techniques and mechanisms used by entrepreneurs in the construction of new ventures and new markets (Venkataraman et al., [6]). They depict "how elements of internal environment of the organism (the entrepreneur's cognition, emotion, actions, and aspirations) interact with elements of external environment (be they market structures, institutions or institutional voids, stakeholders, resources, or cofounders)" (idem, p.23 ). They cite as an example of such mechanisms, among others, bricolage [7], exaptation [8], improvisation [9], or transformation [10]. Hence entrepreneurship is rather seen as an activity and a state of mind than a status or a collection of psychological traits. Opportunities and the environment are making entrepreneurship as much as entrepreneur personality. Hence being an entrepreneur is not only a situation as owner of the business $\mathrm{s}$ /he has created, a mindset as risk-taking, an attitude as discovering, evaluating and exploiting business opportunities, a social image positively evaluated by many social groups, and in many countries a social status, regarding taxes and social insurances.

It is precisely these opportunities and the environment that were profoundly altered by new forms of employment at the frontier between entrepreneurship and work force. "Particular employment situations" appeared especially in the 70s when economic growth slowed down [11]. Yet more radical hybrid alternatives between salaried work and entrepreneurship, blurring the distinction between these two work forms, are much more recent. This development is partly explained by the development of new technologies (see [3]) but, as Reynaud [4] points out, also by the re-centering of many companies on their core competences, leading them to outsource peripheral functions and thus employees occupying the corresponding positions. These functions are subcontracted to service companies or to independent workers. The industry of service to companies is developing, allowing the creation of new businesses and more jobs in the form of temporary missions in other companies. These self-employed, independent workers use a variety of statuses in a kind of "institutional bricolage", where wage labor, entrepreneurship and especially hybrid forms of employment are tried and sometimes carried out simultaneously. The choice of a status for this category of workers seldom looks like a radical plunge: "It is very rare to observe a unique and irrevocable decision, an abrupt change; the process is long, made of trial and error, and subject to frequent adjustments among the same professional project; it is also reversible, returning to a salaried position being one possible step among others." [4, p.304].

Another reason for the development of new forms of employment is institutional. Values of autonomy, accountability, self-realization, freedom of choice and empowerment are promoted, one has to become an entrepreneur of the self (Rose [12]), while workers also demand as a counterpart attention, care and assistance [13].

Such employment situations seem paradoxical if we keep the distinction between entrepreneurship and wage labor. Indeed, these workers are "employees without bosses" [5], "entrepreneur employees" [14] or "autonomous professionals" [4]. All phrases stressing both the hybrid and the paradoxical nature of these developments.

However, still very little is known about motivations driving qualified professionals, having opportunity to be either employees or entrepreneurs, to choose for such hybrid employment situations, about how they experience this situation, as well as about their main desires, fears and values. Previous studies attempted to identify objective reasons 
behind these choices rather than the subjective experience and the representations of these professionals. It is likely that a better comprehension of the subjective experience will provide additional understanding about the development of these new forms of employment.

In a previous research [13] on professionals in such a hybrid situation, the hybrid workers were representing themselves as entrepreneurs, and never as employees. And if they had made a "leap of faith", as is described in the entrepreneurship literature $[6$, p.30], they were also expressing an indispensable need for security and guarantees. They were clearly risk-adverse. Our conclusion by the time were that if the transition from salary-earning to hybrid forms of employment take the psychological shape of a leap, this leaps are undertaken with a "jumping safety net" and that hence we would probably have to redraw the border between entrepreneurship and wage labor. This paper is part of the exploration of this previous conclusion.

\section{Method}

In order to shed light on our two research questions, we opted for a qualitative research. Work trajectories of ten professionals in a rapidly growing form of hybrid employment, the "portage salarial", a French form of umbrella company, were analysed. At the border between wage labor and entrepreneurship, the portage salarial is a newly regulated French labor law status, reserved for executives. Within this status, the employee has to find by him or herself his or her activity but then becomes an employee of an umbrella company. The link between all them is established through a double contract: the umbrella structure signs a contract with the company in which the professional will carry out the service, and at the same time the professional signs an employment contract with the umbrella company, of which he or she then becomes an employee for the time of mission. If the professional has a high level of expertise, he or she will in general benefit from a higher salary than $\mathrm{s} /$ he used to have as an employee of an IT company contracting with the client, while enjoying all employees social benefits and protections (except guarantee of employment). When the mission is completed, if no other mission is found, s/he must resign from the umbrella company.

All our respondents belong to the same umbrella company, specialized in information systems, information technology and telecommunications. It advertizes of supporting experts that remain "independent". All respondents are at executive levels. Respondents have been chosen with a significativity purpose, not one of representativity: the largest diversity in terms of age, gender, length of experience of such occupation, etc. was favored. Nevertheless we kept a certain homogeneity in terms of activity sector (IT) and of qualification level (highly qualified professionals).

This study entails a series of 10 open-ended interviews, in which the respondent is asked to express him/herself about 1/his/her conception of entrepreneurship, 2/his/her experience of his/her new status, professional activity and way of life, and $3 /$ his/her aspirations, fears and both professional and existential values. Open-ended interviews are chosen in order to let them express which aspects are of main importance to them, and to overcome as much as possible politically correct discourses and impression management.

Interviews were analyzed in two steps. We firstly used thematic coding. The themes that emerged were then sorted according to the three previous areas. We thus got a first stream of answers to our questions. A first analysis of responses led us see many contradictions present in the same speech, and the very wide variety of motives. For example, a respondent was using the exact same speech one could expect from a decision of becoming an entrepreneur, an exemplar of the plunge decision (using phrases such as "I dared" or "I got freed up"), whereas objectively his situation had not changed at all (except for the contact). Another claimed to have an "entrepreneurial spirit" and being happy to belong to "another world" than one of employees, whereas at the same time he admitted regrets not having tried to turn his last long assignment (three years) into a permanent contract in the client company.

Such responses were not understandable in the frame of our first coding. We had to find ways of making sense of such speeches. We thus added a second interpretative step. We were then inspired by the reflexive interviewing approach presented by Alvesson[15]. The various moments of the interview were analyzed as either depicting the respondent's views, or being influenced by the social interaction with us, or else by the local features and present moment of the situation. Reflexivity was used as to sort out different kinds of speeches, and to reflect on our own ways of interpreting. We hope to have spotted what pertains to the social performance our respondents were showing, and also to have adequately taken into account the meaning of such a social performance. Presentation of self is crucial to this kind of workers, and to their successes, while a certain amount of self-delusion could not be excluded.

\section{Findings and Discussion}

We posited our first hypothesis that the professionals' leap towards their portage salarial situation would not look like a great plunge, a leap of faith, but rather a leap with a jumping net. This assumption stemmed from the existence of the many guarantees and protections offered by the salaried status. Hence there was the presupposition that anyway the decision came within the province of a leap, whether secured or radical. However, after analyzing our corpus, we begin to put the very concept of a leap into perspective.

Most of our respondents were previously working in a computer service company, working with assignments in outside companies. Their activities were not transformed. They have continued the same activity, while seeking their 
own missions and enjoying a higher salary - some even subcontracting this job search to specialized companies. Instead of a rupture, it may rather be continuity that was sought out. The portage salarial status represented an opportunity to practice their profession the way they wanted, not to create new ones. It was rather a means to focus on their own core competences getting rid of the part of their job they enjoyed the least.

Some of our respondents were indeed considering starting a business, here the portage only playing as a transition phase. However this project was envisaged only on a quite long-term horizon. So again the idea of a leap could be reconsidered. As a matter of fact, the three possible futures were considered by our respondents: those who hoped to find a permanent contract, those who think of starting (at term) their own business and those who want to continue with the umbrella system. The portage salarial is not only a walkway to entrepreneurship. It may also be the best solution for the moment (or sometimes a desired long-term status). The phrase "solution" was recurring. It shows that this hybrid solution was an opportunity at hand to face the present situation, seldom being desired for itself.

More generally, whichever of the three previous options is envisaged, the seizure of another status will much depend on what is available: the kind of assignments, remuneration and work conditions. However, after having experienced a certain extent of freedom thanks to the portage salarial situation, requirements and constraints of a conventional job (their past condition) are viewed negatively. The salaried situation is portrayed as a repellent picture. Security of employment is mainly popular for those who have more difficulty or fear of not finding new assignments, usually the most aged workers. They are more inclined to accept or to look for permanent contracts. For those who experience no difficulty to find new activity opportunities, there is no fear of being unemployed (at least in the short term).

Concerning the second hypothesis, that the experience of hybrid kinds of employment may make us redraw the border between entrepreneurship and wage labor, the findings are all the more striking. On the one hand, the negative depiction of the salaried condition is certainly the most common feature of all respondents and is especially striking in a region where having a permanent contract is often viewed as a condition for happiness. The salaried condition is represented as de-motivating, dis-engaging and bureaucratic, and failing to provide the expected attention and recognition. The salaried workers are said to think firstly to holidays and to come back from work as early as possible. This would prevent them to dedicate themselves fully to their job, and to not get the corresponding rewards.

One the other hand, should one consider the transition from one status to the other as a leap or as a small step, most respondents feel that they have switched to another world. Most of them display a representation of self as entrepreneurs, putting upfront a social status conceived of as prestigious. This is the first dimension in which the concept of entrepreneurship is put into question. While considering themselves as entrepreneurs, they stress the advantage of their social protection in case of unemployment, they fear of having to take care of all the administrative (and strategic) implications of running an independent business, or are afraid of fiscal controls.

To understand this, we need to dig deeper into the motives, desires, fears and values that drive professionals who opt for such a status. Here the main motivation seems to be the possibility to focus on their activity according to their own conception of work. The portage salarial condition allows them to break free from the bureaucracy and administrative tasks. Here we find a significant result of our study, with one exception, all interviewees showed great satisfaction in the exercise of their profession. Somehow these are people close to the idea of "profession-passion ", to use the phrase of one respondent.

Their new condition transports them into a completely different state of mind. As we have said, the majority of respondents portrays itself as entrepreneurs and feels that they experience a highly different situation to the "classical" salary-earning state. They do not feel as being employees. A striking difference becomes drawn between being an entrepreneur (or feeling like being an entrepreneur) and opening a new business. So there is a dissociation between the image of the entrepreneur and the business creator. The entrepreneur here is the one who is not salaried (nor unemployed), who has to find his or her own activity.

Inquiring into this state of mind, we find that one of its key distinctive features is the relation to time. Even if they declare working much more (in number of hours) than in a conventional job, many can benefit from teleworking and manage their time in their own way. They are totally drowned inside the present, or in the confined time of the present assignment, not projecting themselves into a more distant future. There is nothing like a career plan - their only concern for the future is the maintenance of their employability through the continuous education gained by working on their project. Time is their most valuable resource. Time is before all a billable time: having holidays means earning less revenues ("time is money"). They admit that they lack time (so many told us they do not have time for an interview), but they do not complain about it. One respondent said that it is at the end of the day a good problem because if they indeed have less time for their personal life, their occupation is more fulfilling. Investing in their own activity seems to be the main concern. They are before all entrepreneurs of their selves.

In this context, the main fear is not to work, for example by getting sick, because they could not charge their activity and would earn less money. The most aged respondents are very aware of the difficulty of finding a salaried position when they are over fifty. The portage salarial is then a solution for carrying on their activity.

On the one hand, these are professionals who are willing to lead their activity in their personal way, in an engaged and dignified fashion. They find this hybrid form of employment as fulfilling and as offering the possibility to demonstrate 
their excellence. On the other hand, this situation is surrounded by the threat of not finding new projects. It suits well to highly qualified experts, confident in their capacity of finding always new contract opportunities. For others, it can be a transient state, as they consider the possibility switching to a permanent contract (if they find one) or to start a business (but this remains a remote project).

Hence they find in the hybrid forms of employment a possibility for a more autonomous and engaging activity, for choosing the project they work on, and for avoiding a subordination that has become unbearable to them. However, the threat of precariousness is never absent. Sometimes they find it exciting and rewarding, some other times they find it a cause of anxiety. And we may wonder whether this accounting relationship with time would not be the result of our present time pressure for excellence and for fulfillment through work in a liquid society always asking for more flexibility, and allowing survival only for the fittest.

\section{Conclusions}

Hybrid forms of employment are developing throughout Europe. The portage salarial is one of these hybrid forms that contribute to redraw the border between entrepreneurship and wage labor. These professionals have the social status (social benefit) of employees but without subordination. They feel they have the entrepreneurial spirit but without creating new products / markets. Entrepreneurship here is a social status, a specific relation to time, and before all the rejection of the subordinate position.

This hybrid situation is not always a transition to entrepreneurship, in the sense of entrepreneurship studies. This situation can lead to a return to a salaried position or be a permanent situation. The new status seldom leads to a transformation of the activity itself but is experienced as a plunge away from bureaucracy, and as the possibility to exercise one's occupation with a renewed dignity.

Our contribution is two-fold. First, as regard to policy making seeking to foster employment by developing entrepreneurship: a significant number of highly-qualified salaried workers would be willing to create their own business and become independent if a legal status was to define and protect their activities, help them overcome certain fears, and enable them to exercise their expertise without excessive administrative loads. Second, as informing the choice of those considering becoming hybrid workers: they need to be ready to change their attitude towards time.

The consequences of these new employment situations are still to be inquired about. On the positive side, we met professionals highly motivated, even passionate with their work, and finding the opportunity to choose their projects and engaging themselves completely. They immerge themselves into their activity in a fulfilling fashion and often benefit from higher remunerations. On the negative side, they avoid the question of the future. "The future? I do not know", said one respondent. New fears arise about health, ageing, security of incomes (even though they are not worded or with difficulty), making respondents claim for new and augmented protections and care. Our research highlights the need to reflect on the status for these professionals.

It is likely that the concept of hybridization between entrepreneurship and salary-earning fails to capture all the features of such an employment form. By proposing a third possibility, it may help us better understand what entrepreneurship and what salaried work entails. However more research is needed about how these employments are experienced, and about the many possible trajectories to and from these employment forms. The present study presented only the first brush strokes of a picture of a new breed of salaried entrepreneurs. Also, more international comparisons would allow for a better understanding and better advice for the professionals, umbrella company owners and policymakers.

\section{Acknowledgements}

This research was conducted with the help of a research grant from Umalis Group.

\section{REFERENCES}

[1] S. Shane, S. Venkataraman, The promise of entrepreneurship as a field of research, Academy of Management Review, Vol.25, No.1, 217-226, .2000.

[2] D. S. Sarasvathy, S. Venkataraman, Entrepreneurship as a method: open questions for an entrepreunarial future, Entrepreneurship Theory and Practice, Vol.35, No.1, 113-135, 2011

[3] M. Castells, The Rise of the Network Society, The Information Age: Economy, Society and Culture, Vol. I. Cambridge, MA; Oxford, UK: Blackwell, 1996.

[4] E. Reynaud, Aux marges du salariat : les professionnels autonomes, in F. Vatin, Le salariat: théorie, histoire et formes, La Dispute/SNEDIT, Paris, 2007.

[5] B. Poncin, Salariés sans patron?, Editions du Croquant, Paris, 2004.

[6] S. Venkataraman, S. D. Sarasvathy, N. Dew, W. R. Forster, Reflections on the 2010 AMR decade award: whither the promise? Moving forward with entrepreneurship as a science of the artificial, Academy of Management Review, Vol. 37, No.1, 21-33, 2012.

[7] J. Mair, I. Martí, Entrepreneurship in and around institutional voids: A case study from Bangladesh. Journal of Business Venturing, Vol.24, No.5, 419-435, 2009.

[8] N. Dew, S. Sarasvathy, S. Venkataraman, The economic implications of exaptation, Journal of Evolutionary Economics, Vol.14, No.1, 69-84, 2004. 
[9] K. M. Hmieleski, A. C. Corbett, Proclivity for improvisation as a predictor of entrepreneurial intentions, Journal of Small Business Management, Vol.44, No.1, 45-63, 2006.

[10] N. Dew, S. Read, S. D. Sarasvathy, R. Wiltbank, On the entrepreneurial genesis of new markets: Effectual transformations versus causal search and selection", Journal of Evolutionary Economics, Vol.21, No.2, 2010.

[11] B. Fourcarde, Bernard, L'évolution des situations d'emplois particulières de 1945 à 1990, Travail et Emplois, Vol.52, No.2, 4-19, 1992.

[12] N. Rose, Governing the soul: The Shaping of the Private Self,
Routledge, London, 1990.

[13] G. Guérillot, J. L. Moriceau I. Paes, Fil tendu sur du liquide : plate-forme numérique, portage salarial et besoin de care, in $\mathrm{S}$. P. Alemanno, Communications organisationnelles, management et numérique, L'Harmattan, Paris, 229-239, 2015.

[14] C. Beaucourt, P. Louart, La vogue des salariés entrepreneurs. In J. Allouche (coord.), Encyclopédie des Ressources Humaines, Vuibert, Paris, 428-440, 2003.

[15] M. Alvesson, Interpreting Interviews, Sage Publications, London, 2011. 